Article

\title{
Morphological and Structural Properties of Amino-Functionalized Fumed Nanosilica and Its Comparison with Nanoparticles Obtained by Modified Stöber Method
}

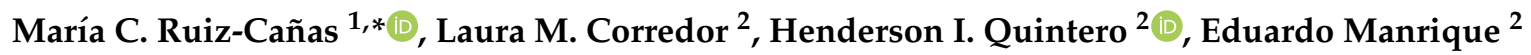 \\ and Arnold R. Romero Bohórquez ${ }^{1, *(D)}$ \\ 1 Grupo de Investigación en Química Estructural, Parque Tecnológico Guatiguará, \\ Universidad Industrial de Santander, A.A. 678, Piedecuesta 681011, Colombia \\ 2 Instituto Colombiano del Petróleo, ECOPETROL S.A., A.A. 4185, Piedecuesta 681017, Colombia; \\ laura.corredor@ecopetrol.com.co (L.M.C.); henderson.quintero@ecopetrol.com.co (H.I.Q.); \\ eduardo.manrique@ecopetrol.com.co (E.M.) \\ * Correspondence: ing.ruizcanasmc@gmail.com (M.C.R.-C.); arafrom@uis.edu.co (A.R.R.B.)
}

Received: 9 May 2020; Accepted: 6 June 2020; Published: 22 June 2020

\begin{abstract}
In industry, silica nanoparticles (NPs) are obtained by the fuming and the precipitation method. Fumed silica NPs are commonly used in the preparation of nanocomposites because they have an extremely low bulk density $\left(160-190 \mathrm{~kg} / \mathrm{m}^{3}\right)$, large surface area $\left(50-600 \mathrm{~m}^{2} / \mathrm{g}\right)$, and nonporous surface, which promotes strong physical contact between the NPs and the organic phase. Fumed silica has fewer silanol groups $(\mathrm{Si}-\mathrm{OH})$ on its surface than the silica prepared by the Stöber method. However, the number of $-\mathrm{OH}$ groups on the fumed silica surface can be increased by pretreating them with sodium hydroxide $(\mathrm{NaOH})$ before further surface modification. In this study, the effectiveness of the $\mathrm{NaOH}$ pretreatment was evaluated on commercial fumed silica NPs with a surface area of $200 \mathrm{~m}^{2} / \mathrm{g}$. The number of surface-OH groups was estimated by potentiometric titration. The pretreated fumed NPs, and the precipitated NPs (prepared by the Stöber method) were modified with 3-aminopropyltriethoxysilane (APTES) to obtain A200S and $\mathrm{nSiO}_{2}$-APTES, respectively. The NPs were characterized using electron dispersive scanning (EDS), scanning electron microscopy (SEM), dynamic light scattering (DLS), Fourier transform infrared spectroscopy (FT-IR), thermogravimetric analysis (TGA), X-ray diffraction (XRD), BET (Brunauer-Emmett-Teller) analysis, and $\zeta$-potential. XRD confirmed the presence of the organo-functional group on the surface of both NPs. After the amino-functionalization, the $\zeta$-potential values of the $\mathrm{nSiO}_{2}$ and $\mathrm{A} 200$ changed from $-35.5 \mathrm{mV}$ and $-14.4 \mathrm{mV}$ to $+26.2 \mathrm{mV}$ and $+11.76 \mathrm{mV}$, respectively. Consequently, we have successfully synthesized functionalized NPs with interesting, specific surface area and porosity (pore volume and size), which can be attractive materials for chemical and energy industries.
\end{abstract}

Keywords: nanoparticles; surface activation; fumed silica; Stöber method; amino-functionalization

\section{Introduction}

Research in nanotechnology over the past few years has resulted in different potential application areas for nanoparticles (NPs) [1-6]. The surface functionalization of NPs is often a precondition for applications where the interactions between components affect the stability of NPs or colloids $[7,8]$. The functionalization of NPs consists of the incorporation of reactive groups on the NPs surface [9-13], which become active sites to bind different molecules (i.e., polymers, composite materials, and elastomers) [14-19]. 
Different organic and inorganic compounds have been used to modify the surface of metal oxide NPs, including carboxylic acids [20,21], polymers [22-26], silanes [27-29], and organophosphorus molecules [12]. However, the silylation method using alkoxysilanes is the most commonly used because it leads to a much stronger interaction between the inorganic and organic phases of a nanohybrid or a nanocomposite [30]. Moreover, the silylation method may improve the stability of the NPs in an organic solvent or an aqueous solution by changing the surface charge or the nature of the NPs (from hydrophilic to hydrophobic) [31,32].

Silane coupling agents have a nonhydrolyzable organic group $(\mathrm{R}-\mathrm{Y})$, which is attached to the surface of the metal oxide NPs and acts as a reactive or a hydrophobic site. It also contains hydrolyzable groups on the silicon atom. The hydrolysable groups are typically alkoxy (i.e., methoxy, ethoxy) [33,34] or chlorine groups [35,36]. The modification of the NPs surface with alkoxysilanes comprises two steps. First, the hydrolysis of the coupling agent produces reactive organosilanols ( $\mathrm{RSi}-\mathrm{OH})(\mathrm{Figure} 1 \mathrm{a})$ and alcohol as a byproduct. Second, the condensation of the organosilanols with the hydroxyl groups on the NPs surface (via Si-O-M covalent bond) occurs to give organofunctional (Figure 1b). The self-condensation of the silane coupling agent can also take place in this step (Figure 1c). Organofunctional groups include amine [33,34,37], acryloxy [38-40], epoxy [41], isocyanate [22], and thiol [42] groups. If the organofunctional group is reactive, it can be covalently attached to a polymer matrix through radical chain transfer, addition, and cyclization reactions. For non-reactive groups, the silane can only improve the compatibility with the polymer matrix due to their similar polarities [43]. For practical purposes, the conditions of functionalization, modification, and preparation of desirable materials should be carefully optimized.

(a) Hydrolisis<smiles>[R]O[Si](C[14CH2]O)(O[R])O[R]</smiles>

(b) Condensation

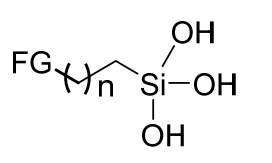<smiles>O=C1C(O)C(O)C(O)C(O)C(O)C1O</smiles>

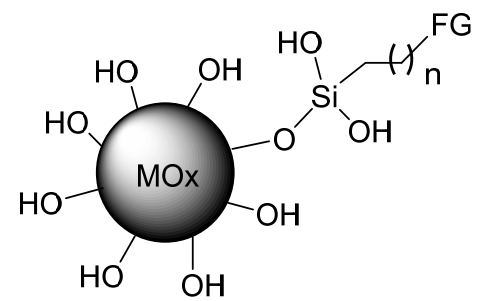

(c) Self-condensation

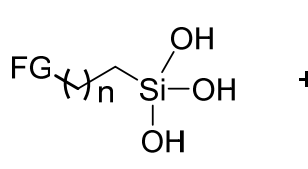

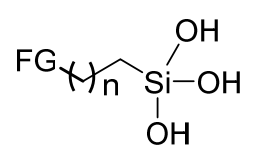<smiles>COCCO</smiles><smiles>O[Si](O)(CC=[18O])O[Si](O)(O)CC=[18O]</smiles>

Figure 1. Scheme of the modification of metal oxide particles with an alkoxysilane derivative. (a) Hydrolisis; (b) Condensation; (c) Self-condensation. MOx: metal oxide, and FG: H, Hal-, $\mathrm{NH}_{2}, \mathrm{SH}$, acryloxy group, between others.

Silica NPs are produced by two methods: fuming and precipitation. Fumed silica is synthesized by the pyrolysis of silicon tetrachloride $\left(\mathrm{SiCl}_{4}\right)$ in a flame of oxygen-hydrogen (Equation (1)). Precipitated silica is produced by precipitation from silicates and inorganic acids (sol-gel process) [12]. When the sol-gel reaction occurs under alkaline conditions, this is referred to as the Stöber method. Fumed silica has fewer silanol groups $(\mathrm{Si}-\mathrm{OH})$ on its surface than the precipitated one because it is produced at high 
temperatures $\left(>1500^{\circ} \mathrm{C}\right)$. For this reason, fumed silica NPs must be pretreated with sodium hydroxide $(\mathrm{NaOH})$ before any surface modification.

$$
2 \mathrm{H}_{2}+\mathrm{O}_{2}+\mathrm{SiCl}_{4} \underset{\Delta}{\rightarrow} \mathrm{SiO}_{2}+4 \mathrm{HCl}
$$

This work aimed to determine the effectiveness of the $\mathrm{NaOH}$ treatment on the preparation of amino-functionalized silica NPs. The $\mathrm{NaOH}$ treatment was used to activate the surface of commercial fumed $\mathrm{SiO}_{2} \mathrm{NPs}$ with a surface area of $200 \mathrm{~m}^{2} / \mathrm{g}$. After the pretreatment, the fumed and precipitated silica NPs (prepared by the Stöber method) were modified with 3-aminopropyltriethoxysilane (APTES). As stated in the literature, the APTES-modified silica NPs can be used in different fields, such as the preparation of hybrid materials [44-46], medicine [47-50], and many others [37,51,52]. Additionally,

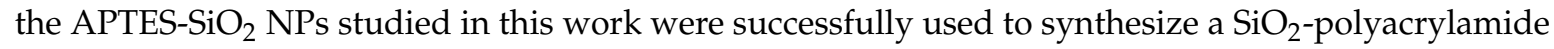
(PAM) nanohybrid. The obtained nanohybrid exhibited better resistance to thermal degradation than the PAM [53].

\section{Materials and Methods}

\subsection{Materials}

Fumed silica NPs (A200) with a surface area of $200 \mathrm{~m}^{2} / \mathrm{g}$ were supplied by Evonik Industries AG (Essen, Germany). Tetraethyl orthosilicate (TEOS, 98\%, Sigma-Aldrich, Louis, MO, USA), ethanol (EtOH, 96\%, Merck Millipore, Burlington, MA, USA), and ammonium hydroxide (28-30 wt \% solutions of $\mathrm{NH}_{3}$ in water, Merck Millipore, Burlington, MA, USA) were used to synthesize the silica NPs by the Stöber method. The activation reaction was carried out with sodium hydroxide $(\mathrm{NaOH}, 97 \%$, Merck, Darmstadt, Germany), methanol $\left(\mathrm{CH}_{3} \mathrm{OH}, 99.9 \%\right.$, Merck, Germany), and acetic acid $\left(\mathrm{C}_{2} \mathrm{H}_{4} \mathrm{O}_{2}, 100 \%\right.$, Merck, Darmstadt, Germany). Further, 3-aminopropyltriethoxysilane (APTES, 99\%, Sigma-Aldrich, St. Louis, MO, USA) was used to functionalize the surface of the activated NPs.

\subsection{Nanoparticle Synthesis}

The silica NPs were synthesized by following the method described by Stöber and Fink [54,55]. For this procedure, $1 \mathrm{~mL}$ ( $4.48 \mathrm{mmol}$ ) of TEOS was added in $32.5 \mathrm{~mL}$ of an ammonium hydroxide/ethanol solution (1:25 ratio). This dispersion ( $\mathrm{pH} 10)$ was stirred for $3 \mathrm{~h}$ at $90{ }^{\circ} \mathrm{C}$. Then, the silica NPs were centrifugally separated from the dispersion and washed three times with deionized water. Finally, the NPs were dried in a conventional oven for $24 \mathrm{~h}$ at $90{ }^{\circ} \mathrm{C}$ and they were named $\mathrm{nSiO}_{2}$.

\subsection{Activation Reaction of the Silica NPs}

The fumed silica NPs (A200) were activated by modifying their surface with hydroxyl ions (-OH) (Figure 2). For this purpose, $4 \mathrm{~g}$ of fumed silica NPs were dispersed in $100 \mathrm{~mL}$ of a $1 \mathrm{M}$ aqueous solution of $\mathrm{NaOH}$. The dispersion was stirred using a magnetic stirrer in a water bath at a temperature between 60 and $70{ }^{\circ} \mathrm{C}$ for $24 \mathrm{~h}$. The dispersing media was neutralized with acetic acid, and the activated silica NPs were recovered by centrifugation. The powder was washed three times with methanol and dried for $24 \mathrm{~h}$ at $120^{\circ} \mathrm{C}$. This procedure was performed based on the method proposed by Lin et al. [56]. The obtained NPs were named A200A.
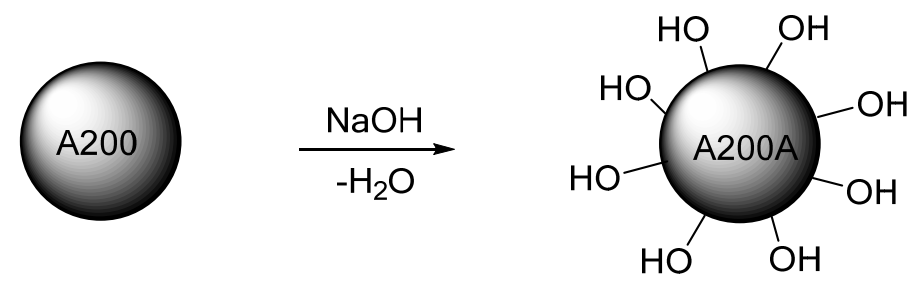

Figure 2. Activation of the fumed silica NPs. 


\subsection{Amino-Functionalization Reaction}

All silica NPs were functionalized with 3-aminopropyltriethoxysilane (APTES) (Figure 3), generating a chemically reactive system. This procedure was performed based on the method proposed by Chen et al. [57]. In this procedure, $4 \mathrm{~g}$ of silica NPs were dispersed in a solution containing $2 \mathrm{~g}$ of APTES and $100 \mathrm{~mL}$ of ethanol. The dispersion was stirred for $3 \mathrm{~h}$ at room temperature. After treatment, the NPs were separated by centrifugation and alternately washed with ethanol and water at least two times to remove excess reagents. Finally, the NPs were dried for $12 \mathrm{~h}$ at

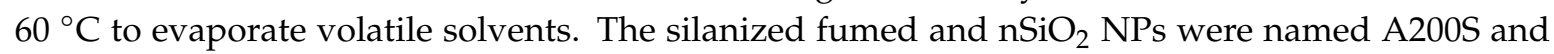
$\mathrm{nSiO}_{2}$-APTES, respectively
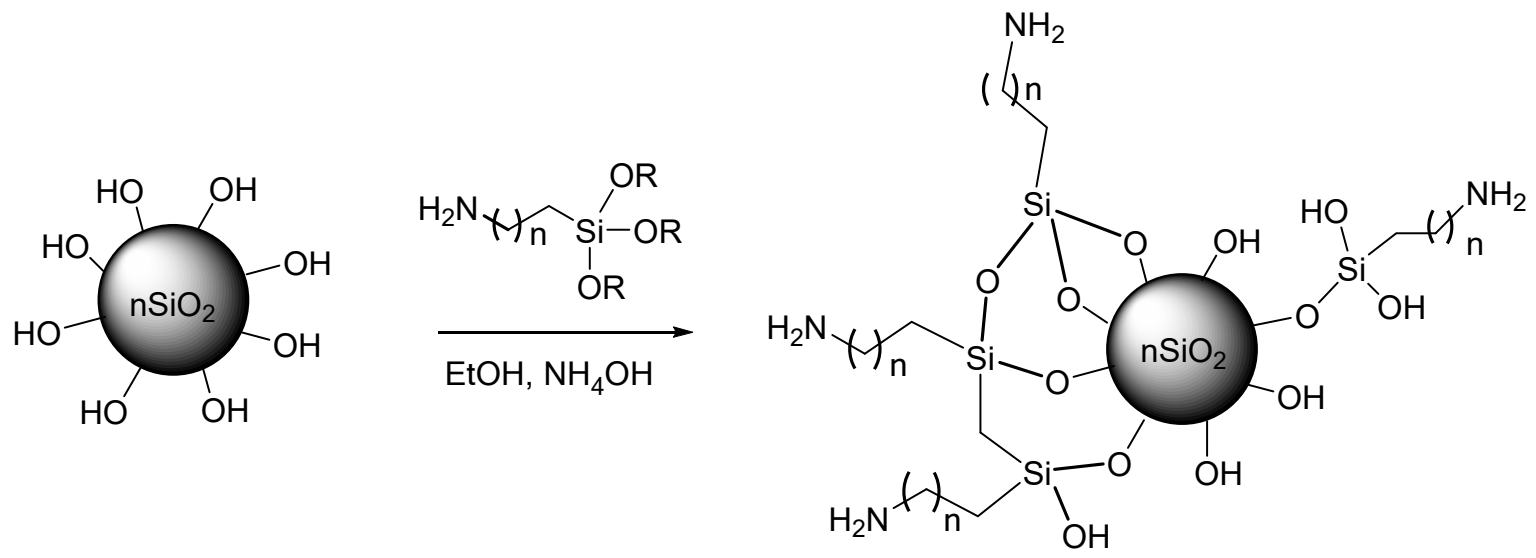

Figure 3. Amino-functionalization of the silica NPs.

\subsection{Determination of the Hydroxyl Group Content on the NPs Surface}

The content of $-\mathrm{OH}$ groups on the surface of the NPs was estimated by using the titration method described by Kang et al. [58]. In this method, $2 \mathrm{~g}$ of treated silica NPs were added into a bottle containing $80 \mathrm{~mL}$ of a $0.05 \mathrm{~N}$ aqueous solution of $\mathrm{NaOH}$. The bottle was capped and stirred using a magnetic stirrer for $24 \mathrm{~h}$ at room temperature. The NPs were separated by centrifugation, and $10 \mathrm{~mL}$ of the supernatant were taken for titration. The indicator was prepared by adding $0.5 \mathrm{~g}$ of phenolphthalein into $100 \mathrm{~mL}$ of a mixture of water and ethanol (50\% $v / v)$. Then, three drops of the phenolphthalein solution were added into $10 \mathrm{~mL}$ of the supernatant. This sample was titrated until neutralization (when the color of the solution changed from magenta to transparent) with a $0.05 \mathrm{~N}$ aqueous solution of $\mathrm{HCl}$. The same procedure was carried out for a blank solution (0.05 $\mathrm{N}$ aqueous solution of $\mathrm{NaOH}$ without silica NPs). For determination of the hydroxyl group content on the NPs surface, the corresponding Equation (2) was employed. Each titration was repeated at least three times to confirm the reproducibility, with the uncertainty found to be of the order of $0.01 \mathrm{mM} / \mathrm{g}$ of the reported value.

$$
X=\frac{(B-A) \times 0.05 \times C}{W}
$$

where $X$ is the amount of $-\mathrm{OH}$ groups per unit weight of silica NPs $(\mathrm{mM} / \mathrm{g}), A$ is the volume of $\mathrm{HCl}$ used to neutralize the sample containing NPs $(\mathrm{mL}), B$ is the volume of $\mathrm{HCl}$ used to neutralize the blank solution (mL). $W$ is the amount of silica NPs used for the test and $C$ is the ratio between the total volume of the solution $(80 \mathrm{~mL})$ and the aliquot volume $(10 \mathrm{~mL})$.

\subsection{NPs Characterization}

A field emission gun scanning electron microscope (FEG-SEM) operating at an acceleration voltage of 25 kV (FEGSEM, QUANTA FEG 650 model, Thermo-Fisher Scientific, Waltham, MA, USA) was used to determine the size and morphology of the NPs. Each sample was placed on metal stubs with carbon 
adhesive tape and coated with gold using a Quorum 150 ES coating equipment (Quorum Technologies Ltd., Lewes, UK). The FEG-SEM images were obtained from the Everhart Thornley (ETD) and the backscattering electron detectors. The elemental composition of the NPs was determined by using an energy-dispersive spectroscope (EDS, EDAX Apolo X, Ametek, Inc., Berwyn, PA, USA) operating at an acceleration voltage of $25 \mathrm{kV}$.

The degree of crystallinity of the NPs was determined by X-ray diffraction at $2 \theta$ from $2^{\circ}$ to $70^{\circ}$ (Bruker D-8 A25 DaVinci, Bruker, Billerica, MA, USA). The patterns were recorded by a CuK $\alpha$ radiation source and a lynxEye detector at $0.6 \mathrm{~mm}$ divergence slit, $2.5^{\circ}$ primary and secondary Soller slits, $40 \mathrm{kV}$ accelerating voltage, and $40 \mathrm{~mA}$ current. The samples were loaded on polymethyl methacrylate (PMMA) holders with a Si center using the zero-background technique.

Attenuated total reflection Fourier transform infrared spectroscopy (ATR-IR-FT) using a Bruker Tensor 27 FTIR spectrometer with a platinum cell (Alpha, Bruker, Billerica, MA, USA) was used to perform the structural characterization of all NPs. The FTIR spectra were recorded from 600 to $4000 \mathrm{~cm}^{-1}$ with a resolution of $4 \mathrm{~cm}^{-1}$ (24 scans were taken every $30 \mathrm{~s}$ for each spectrum).

The $\zeta$-potential measurements were performed by using a Zetasizer ZS90 (Malvern Instruments, Herrenberg, Germany) equipped with a high concentration flow cell. Then, 100 ppm of NPs were dispersed in distilled water and sonicated for $15 \mathrm{~min}$ before measurement. The average $\zeta$-potential value was calculated from three sets of measurements analyzed by the Zetasizer software version 7.13 , where each measure was the mean of 50 individual runs carried out at different positions (10 measurements in 5 positions) in the flow cell. This analysis had an uncertainty of $0.5 \mathrm{mV}$ at $25^{\circ} \mathrm{C}$.

The hydrodynamic ratio of the NPs was determined by dynamic light scattering (DLS) analysis using a Zetasizer Nano ZS90 equipped with a $633 \mathrm{~nm}$ He-Ne laser (Malvern Instruments, Herrenberg, Germany) at an angle of $90^{\circ}$ and $30^{\circ} \mathrm{C}$. For this test, $100 \mathrm{ppm}$ of NPs were dispersed in deionized (DI) water. The dispersions were analyzed in a glass cell with a path length of $10 \mathrm{~mm}$. The measurements were made at a $4.65 \mathrm{~mm}$ position from the cuvette wall using an automatic attenuator and equilibrium time of $180 \mathrm{~s}$. Fifteen runs of $10 \mathrm{~s}$ were performed with three repetitions for each sample. The uncertainty in DLS results is $5.8 \mathrm{~nm}$ of the reported value. The software used to collect and analyze the data was the Zetasizer software version 7.13. The size distribution as a function of the intensity, the average diameter Z (Z-average), and the polydispersity index (PdI) were obtained from the autocorrelation function using the "general-purpose mode" for the monodispersed NPs.

A fundamental parameter in the characterization of porous solids is their specific surface area. These measurements were conducted by using an ASAP 2020 specific surface analyzer (Micromeritics, GA, USA). Before each test, the sample was vacuum degassed at $398.15 \mathrm{~K}$ for $6 \mathrm{~h}$. The surface area was measured by the low temperature $(77 \mathrm{~K})$ adsorption of nitrogen and calculated by the Brunauer, Emmett, and Teller (BET) method. The pore size distribution was calculated using the Barrett-Joyner-Halenda (BJH) method. The pore volume measurement allows estimating the degree of functionalization on the surface of the pores by comparing the pore volume of the functionalized with the non-functionalized NPs [59].

The thermal properties of the NPs were analyzed by thermogravimetry using a TA2050 TGA analyzer (TA Instruments, INC., New Castle, DE, USA). For the measurements, a mass of $5 \mathrm{mg}$ of sample was heated from 25 to $800{ }^{\circ} \mathrm{C}$ at a nitrogen flow of $25 \mathrm{~mL} / \mathrm{min}$ and a heating rate of $10^{\circ} \mathrm{C} / \mathrm{min}$. Thermogravimetric analysis (TGA) allows for the determination of the organic matter content and the degree of functionalization in the NPs [60].

\section{Results and Discussion}

\subsection{Determination of the-OH Groups Content on the NPs Surface}

The content of the $-\mathrm{OH}$ groups on the NPs surface (A200, A200A, and $\mathrm{nSiO}_{2}$ ) was quantified by potentiometric titration and calculated using Equation (2). The content of $-\mathrm{OH}$ groups calculated

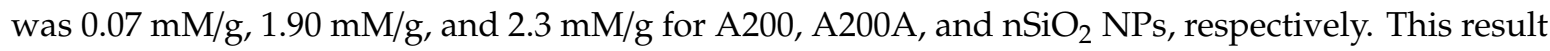


showed that $\mathrm{NaOH}$ activated the A200 NPs surface by increasing the $-\mathrm{OH}$ content on their surface by $96 \%$. In addition, the content of $-\mathrm{OH}$ groups of the A200A NPs $(1.90 \mathrm{mM} / \mathrm{g})$ is higher than that previously reported in the literature $(1.1 \mathrm{mM} / \mathrm{g})$ [56].

\subsection{SEM-EDS Results}

Figure 4 shows the micrographs of A200, A200A, A200S, and $\mathrm{nSiO}_{2}-\mathrm{APTES}$ NPs. The A200 NPs aggregated forming microspheres (Figure $4 \mathrm{a}, \mathrm{d}$ ) to reduce their high surface energy, resulting from their large surface-volume ratio. Moreover, the pretreatment with $\mathrm{NaOH}$ promoted the formation of aggregates, mainly as micron-size granules, due to the hydrogen bonding between the silanols on the surface (Figure $4 \mathrm{~b}, \mathrm{e}$ ). The A200S NPs (Figure 4c,f) has an amorphous morphology and an average size of $60 \mathrm{~nm}$. The $\mathrm{nSiO}_{2}-\mathrm{APTES}$ have a near-spherical morphology and average size of $141 \mathrm{~nm}$ (Figure 4g-i) [53].
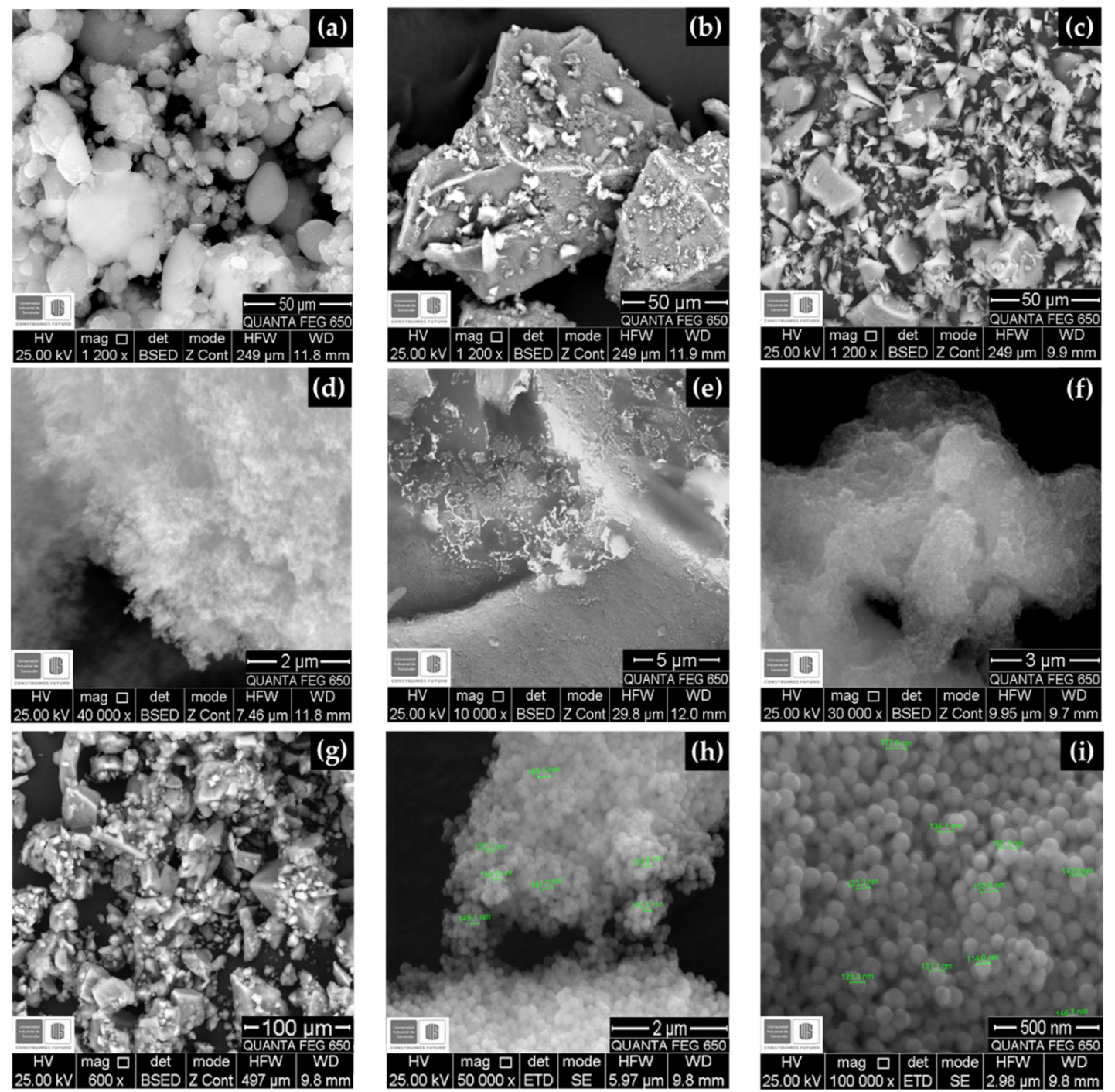

Figure 4. SEM micrographs of (a,d) A200 NPs at 1200× and 40,000×, respectively; (b,e) A200A NPs at $1200 \times$ and $10,000 \times,(\mathbf{c}, \mathbf{f})$ A200S NPs at $1200 \times$ and $30,000 \times$ and $(\mathbf{g}-\mathbf{i}) \mathrm{nSiO}_{2}-\mathrm{APTES}$ NPs at $600 \times, 50,000 \times$ and $100,000 \times$, respectively.

Figure 5 shows the EDS results of A200, A200S, and $\mathrm{nSiO}_{2}-\mathrm{APTES}$. The presence of $\mathrm{C}$ and $\mathrm{N}$ on A200S NPs confirms the attachment of the APTES onto the NPs surface (Table 1). 

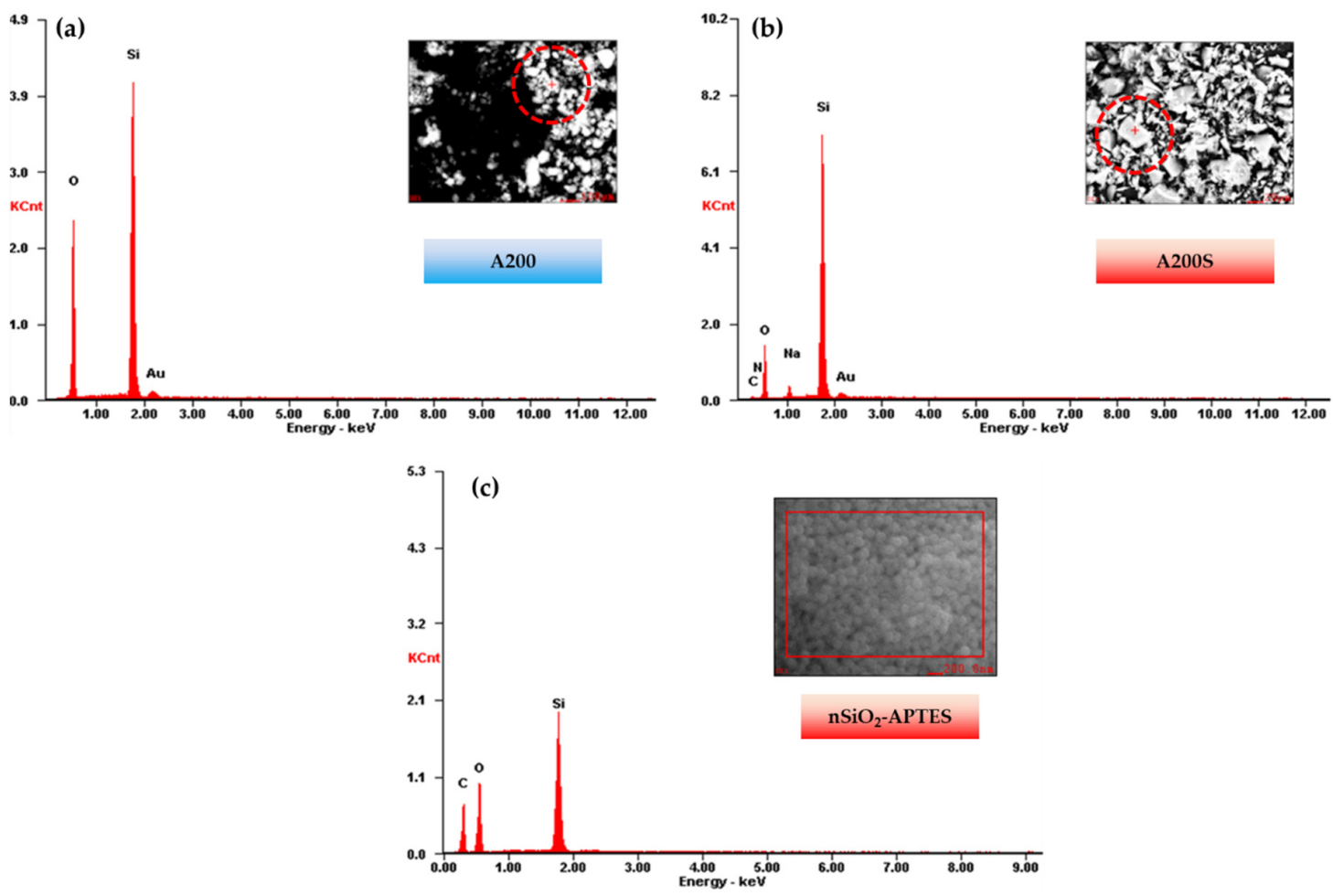

Figure 5. EDS results of (a) A200, (b) A200S and (c) $\mathrm{nSiO}_{2}$-APTES NPs.

Table 1. Weight and atomic percentage of A200, A200S and $\mathrm{nSiO}_{2}-\mathrm{APTES} S$ NPs by EDS analysis.

\begin{tabular}{ccccccc}
\hline \multirow{2}{*}{ Element } & \multicolumn{2}{c}{$\mathbf{A 2 0 0}$} & \multicolumn{2}{c}{ A200S } & \multicolumn{2}{c}{ nSiO $_{2}$-APTES } \\
\cline { 2 - 7 } & $\mathbf{w t} \%$ & at $\%$ & $\mathbf{w t} \%$ & $\mathbf{a t} \%$ & $\mathbf{w t} \%$ & at $\%$ \\
\hline $\mathrm{C}$ & & & 3.44 & 6.35 & 36.29 & 47.16 \\
$\mathrm{~N}$ & & & 1.17 & 1.85 & 0.50 & 0.50 \\
$\mathrm{O}$ & 53.80 & 65.16 & 32.69 & 45.35 & 41.51 & 40.50 \\
$\mathrm{Si}$ & 36.84 & 25.41 & 53.31 & 42.12 & 22.20 & 12.34 \\
$\mathrm{Na}$ & & & 3.83 & 3.70 & & \\
\hline
\end{tabular}

The relative oxygen content on the surface of A200S NPs decreased from $53.80 \mathrm{wt} \%$ to $32.69 \mathrm{wt} \%$ as compared with the A200 NPs (Table 1). In addition, the functionalization of the NPs is confirmed with the presence of $\mathrm{C}$ and $\mathrm{N}$ in the A200S and $\mathrm{nSiO}_{2}-\mathrm{APTES} \mathrm{NPs}$ surface. The relative content of Si on the surface of $\mathrm{nSiO}_{2}$-APTES (22.20 wt \%) was lower as compared with the A200S (53.31 wt $\%$ ) due to the high surface area of A200 and the presence of silica in the structure

\subsection{X-ray Diffraction (XRD)}

XRD spectra of A200 and A200S NPs are shown in Figure 6. The spectra of A200 NPs exhibit a broad halo peak centered at a $2 \theta$ value of $21^{\circ}$, which confirms the amorphous structure of the NPs [11]. Also, the broad peak around $42^{\circ}$ confirms the amorphous structure in the samples, which means that the unmodified NPs (A200) is highly disordered compared with the modified one (A200S) [61,62]. Upon the amino-functionalization, this signal was shifted to higher $2 \theta$ values. This was attributed to the attachment of the organic functional groups onto the surface of NPs channels, which tends to reduce the scattering power (or scattering contrast) of the amorphous silicate wall [63-65]. 


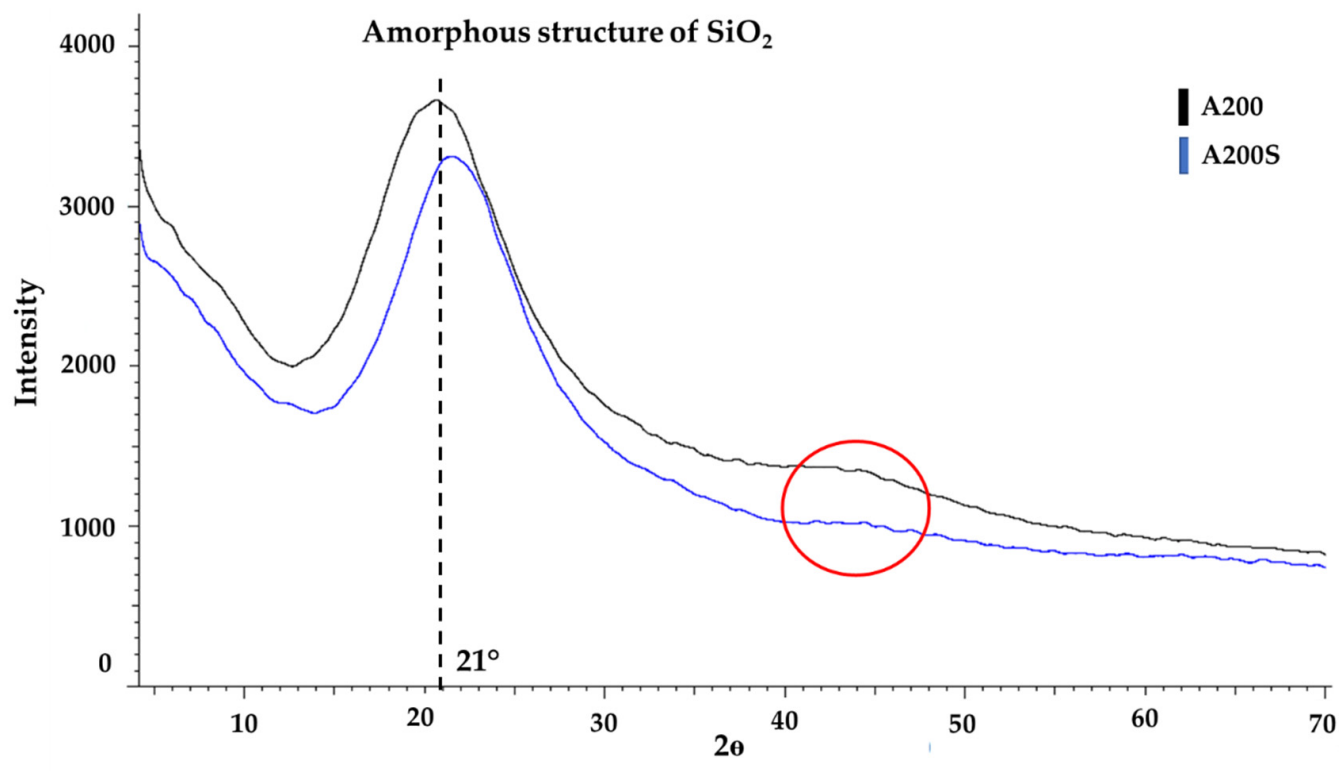

Figure 6. Diffractograms of A200 and A200S NPs.

Comparing A200S and $\mathrm{nSiO}_{2}$-APTES NPs (Figures 6 and 7), a shift of the back of the main halo is observed ( $22^{\circ}$ for A200S and $21^{\circ}$ for $\mathrm{nSiO}_{2}$-APTES). This is attributed to an increment in the interplanar distance. The XRD results confirms that $\mathrm{nSiO}_{2}$-APTES NPs (spherical) have a different structure than the A200S NPs (amorphous).

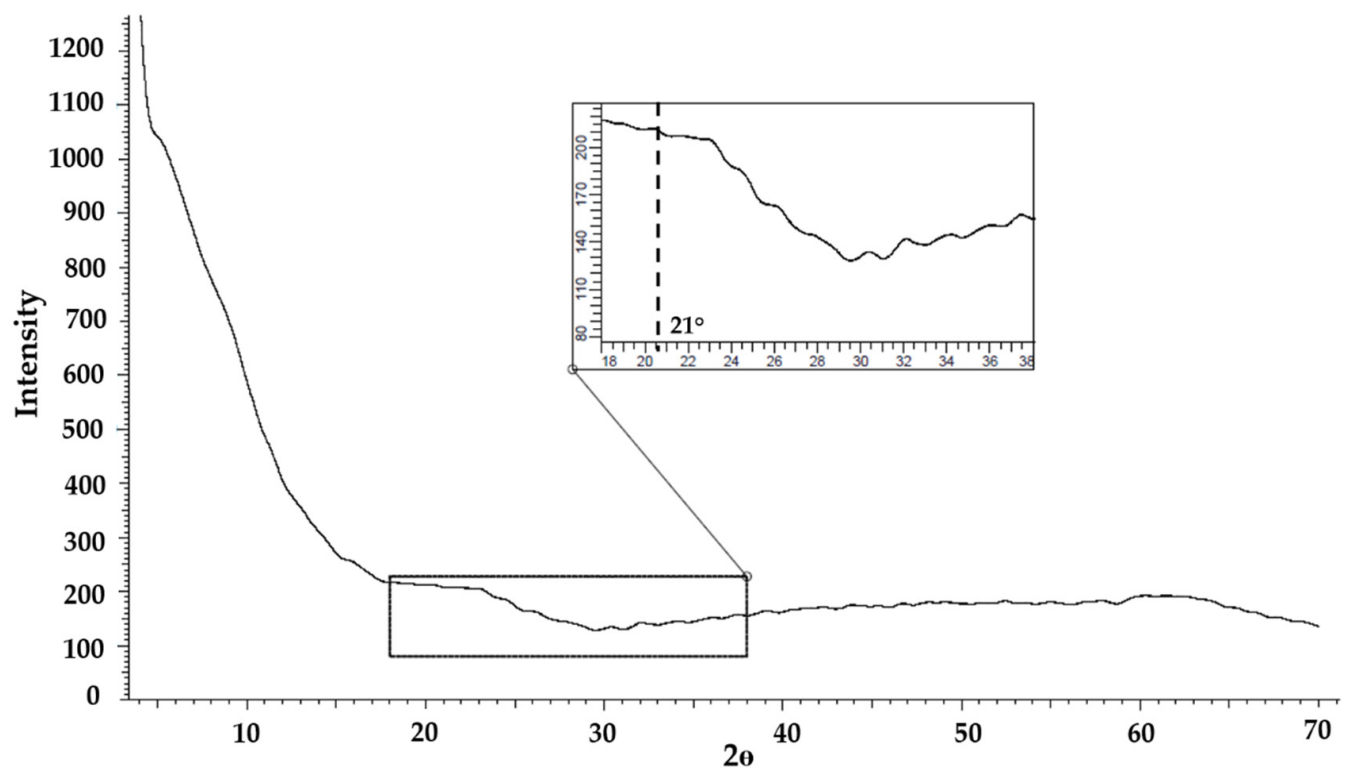

Figure 7. Diffractogram of $\mathrm{nSiO}_{2}$-APTES NPs.

\subsection{FTIR-ATR Results}

Figure 8 displays the FTIR spectra of the A200, A200A, and A200S NPs. The absorption bands at around $1100 \mathrm{~cm}^{-1}$ and $809 \mathrm{~cm}^{-1}$ are attributed to the stretching and bending vibration of the siloxane groups ( $\mathrm{Si}-\mathrm{O}-\mathrm{Si})$, respectively $[66,67]$. Compared to the unmodified NPs, two new adsorption bands at $3446 \mathrm{~cm}^{-1}$ and $1649 \mathrm{~cm}^{-1}$ are observed on the IR spectrum of the A200A NPs (Figure $8 \mathrm{~b}$ ), which are assigned to the stretching vibration of the silanol group ( $\mathrm{Si}-\mathrm{OH})[68,69]$ and adsorbed water in the sample [70], respectively. These results confirm the presence of hydroxyl groups on the surface of the NPs. The A200 modification by APTES is evidenced with the bands at $2974 \mathrm{~cm}^{-1}$, 
and $959 \mathrm{~cm}^{-1}$ (Figure 8c). These bands are attributed to C-H stretching vibration, and the unhydrolyzed ethoxy moieties in the APTES, respectively [32,71-73]. Furthermore, the disappearance of the band at $3446 \mathrm{~cm}^{-1}$ confirms the surface modification of the NPs with APTES.

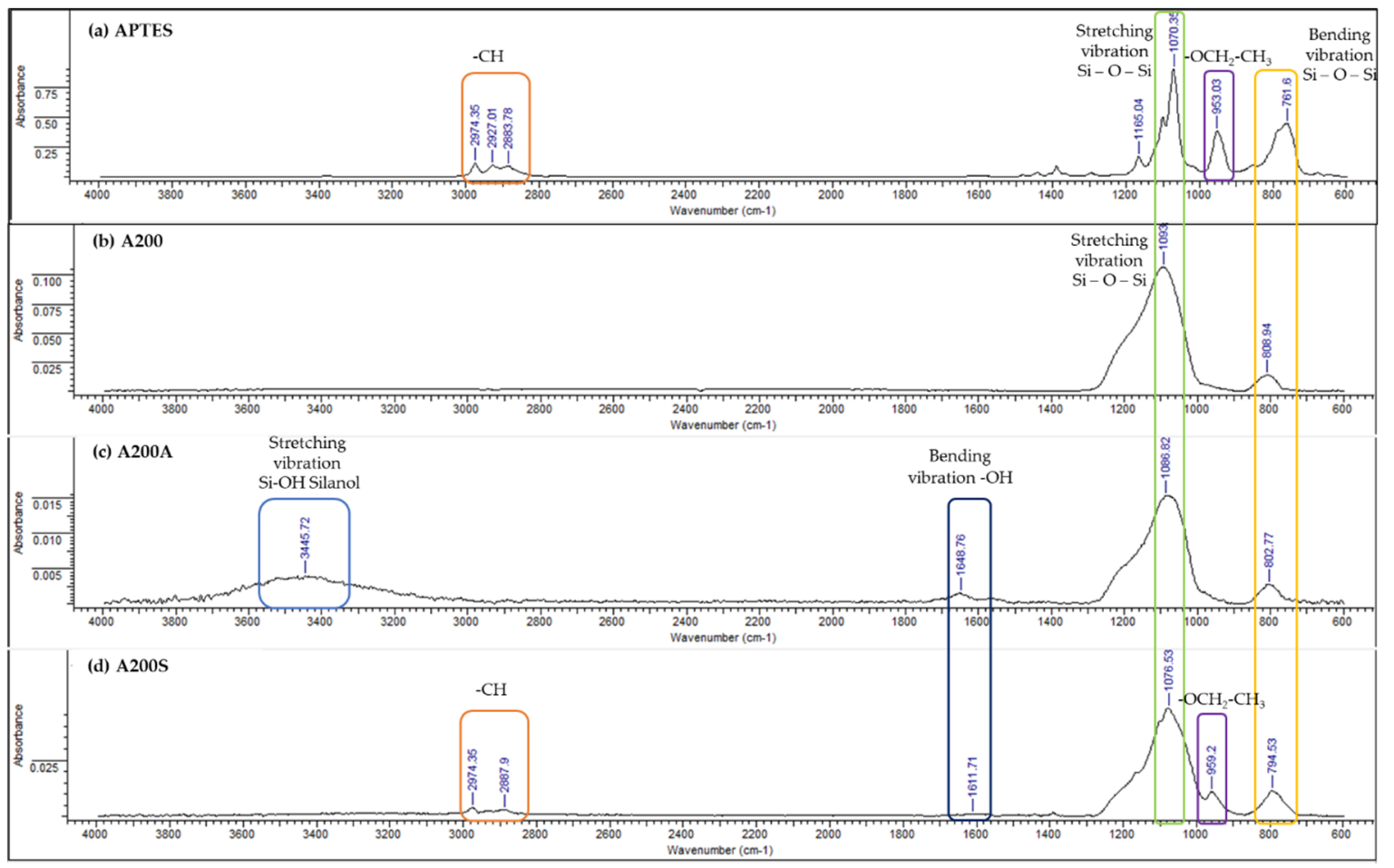

Figure 8. Infrared Spectrum of (a) APTES, (b) A200, (c) A200A and (d)A200S NPs.

The FTIR spectra of APTES, n-SiO 2 , and n-SiO ${ }_{2}$-APTES (Figure 9) show typical bands with the spectra of the fumed NPs reported in Figure 8. The bands at around 1100 and $800 \mathrm{~cm}^{-1}$ are ascribed to asymmetric stretching and bending vibrations of the siloxane groups ( $\mathrm{Si}-\mathrm{O}-\mathrm{Si})$, respectively [69]. In the APTES spectra, the characteristic bands are $2974 \mathrm{~cm}^{-1}$ and $953.03 \mathrm{~cm}^{-1}$, which are assigned to $\mathrm{C}-\mathrm{H}$ stretching vibration and $-\mathrm{OCH}_{2}-\mathrm{CH}_{3}$-vibration, respectively [32]. The $\mathrm{SiO}_{2}$-APTES NPs spectra show a new band at $949 \mathrm{~cm}^{-1}$, which is attributed to the unhydrolyzed ethoxy moieties in the APTES. These results confirm the presence of organic substitution in the modified silica [73].

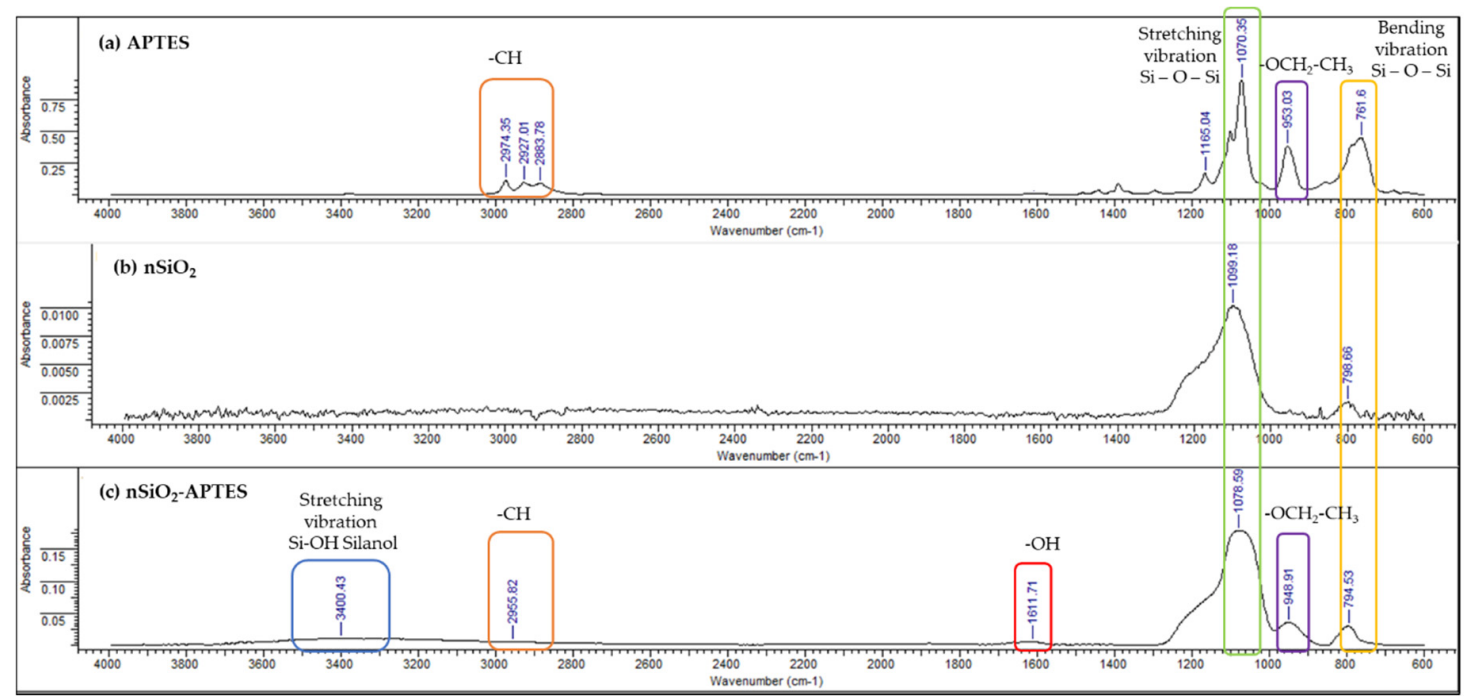

Figure 9. Infrared spectra of (a) APTES, (b) $\mathrm{nSiO}_{2}$ and (c) $\mathrm{nSiO}_{2}-\mathrm{APTES} \mathrm{NPs}$. 


\subsection{Colloidal Stability ( $\zeta$-Potential)}

The colloidal stability of NP dispersions is predicted by the magnitude of the $\zeta$-potential. Dispersions with $\zeta$-potential values greater than $-30 \mathrm{mV}$ or less than $+30 \mathrm{mV}$ are usually unstable due to interparticle attractions [74-76]. The $\zeta$-potential values of all NPs dispersed in distilled water are presented in Figure 10. It is observed that only the $\mathrm{n}-\mathrm{SiO}_{2}$ dispersion is stable, according to the DLVO theory. The higher degree of stability of $\mathrm{nSiO}_{2}$ dispersion, compared to the A200, is attributed to the dissociation of silanol groups on the NPs surface. The absolute $\zeta$-potential value increase of the A200 NPs was consistently observed after the pretreatment with $\mathrm{NaOH}$ (from -14.4 to $-27.6 \mathrm{mV}$ ). Upon the NPs amino-functionalization, the A200S and $\mathrm{nSiO}_{2}$-APTES potential changed to $+11.76 \mathrm{mV}$ and $+26.2 \mathrm{mV}$, respectively. The latter can be directly related to the protonation of the amine group. This effect confirms that enough surface coverage with APTES was achieved. Both dispersions are unstable due to the hydrophobicity of the APTES grafted to the surface.
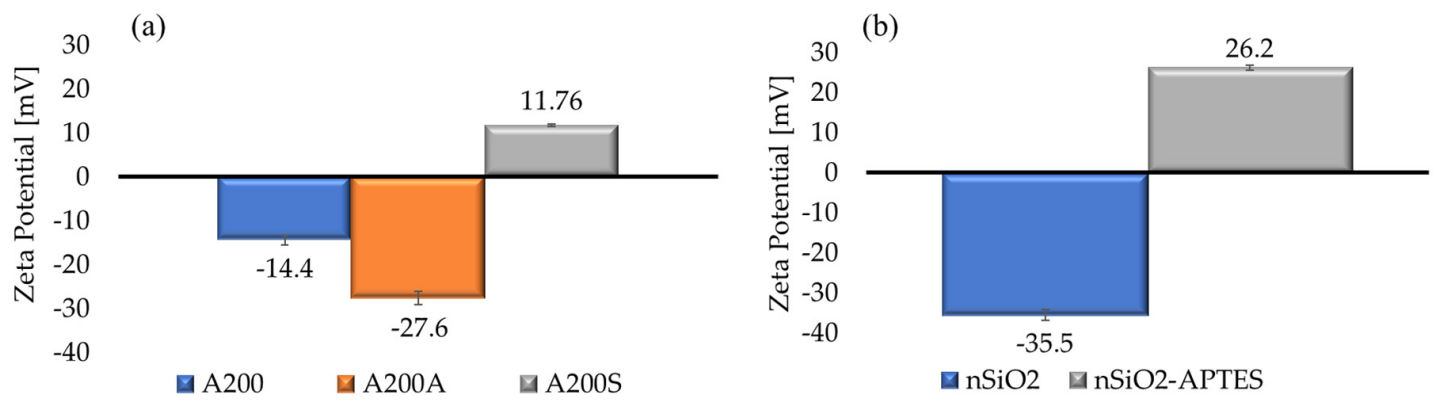

Figure 10. $\zeta$-potential values of (a) A200, A200A and A200S, and (b) $\mathrm{nSiO}_{2}$ and $\mathrm{nSiO}_{2}-\mathrm{APTES} \mathrm{NPs}_{\text {. }}$

\subsection{Hydrodynamic Radius by DLS Results}

After the NaOH pretreatment, the average size of the A200 NPs increased from 164 to $295 \mathrm{~nm}$ (Figure 11). This increase is due to the NP aggregation through the hydrogen bonding between the silanols on the NPs surface. However, the increased stability of the NPs observed in the $\zeta$-potential measurements suggests the formation of a hydration layer that stabilizes the aggregates. For A200S NPs, a broader particle size distribution is observed (high polydispersity). This is attributed to the formation of aggregates due to hydrophobic interactions between NPs, which is consistent with its low $\zeta$-potential value. Similar behavior was observed for the $\mathrm{nSiO}_{2}$ and $\mathrm{nSiO}_{2}-\mathrm{APTES} \mathrm{NPs}$ (Figure 12). However, these NPs showed a smaller hydrodynamic radius and less polydispersity than the fumed NPs. These characteristics make them more stable in aqueous solutions (higher absolute $\zeta$-potential values).

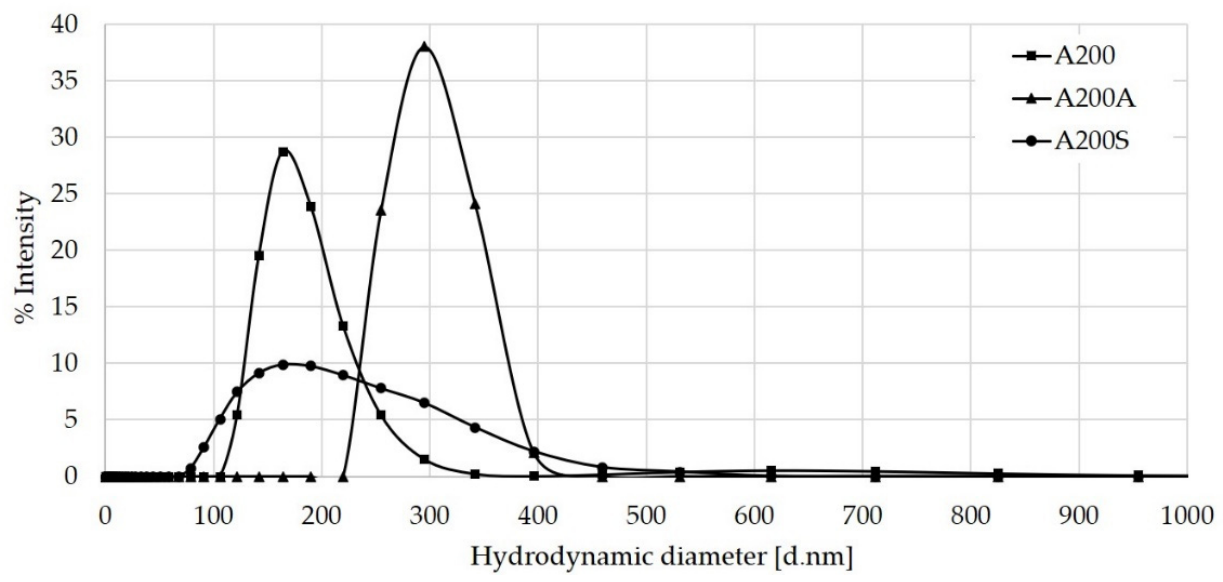

Figure 11. DLS results of A200, A200A, and A200S NPs. 


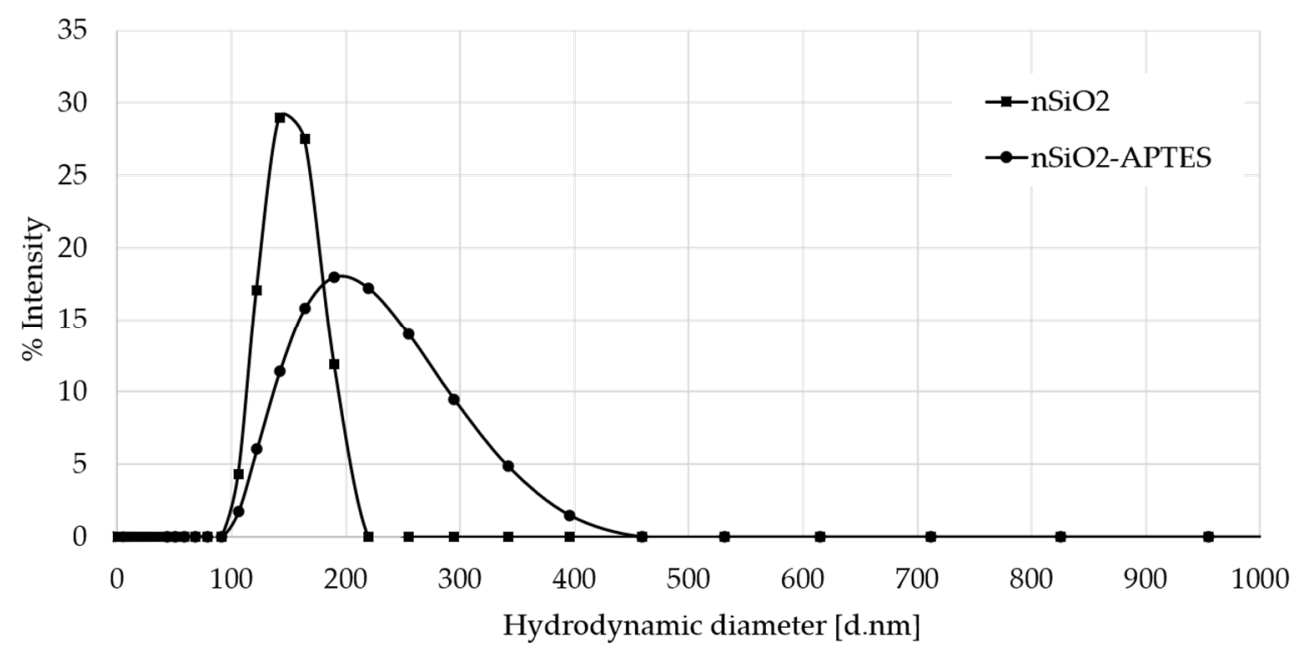

Figure 12. DLS results of $\mathrm{nSiO}_{2}$ and $\mathrm{nSiO}_{2}$-APTES NPs.

\subsection{BET Isotherms}

The specific surface area and pore size of all NPs were calculated from $\mathrm{N}_{2}$ adsorption/desorption isotherms (Figure 13). According to the IUPAC classification [77], all NPs exhibited a type IV adsorption isotherm with a type $\mathrm{H} 1$ hysteresis loop very narrow in the relative pressure range of $0.8-1.0$. This type of isotherm is characteristic of mesoporous materials, and it is characterized by a hysteresis curve caused by capillary condensation in mesopores with open cylindrical cavities [78-80]. According to the results of the BHJ method, all NPs have a pore size in the mesoporous range, between 20 and $500 \AA$.
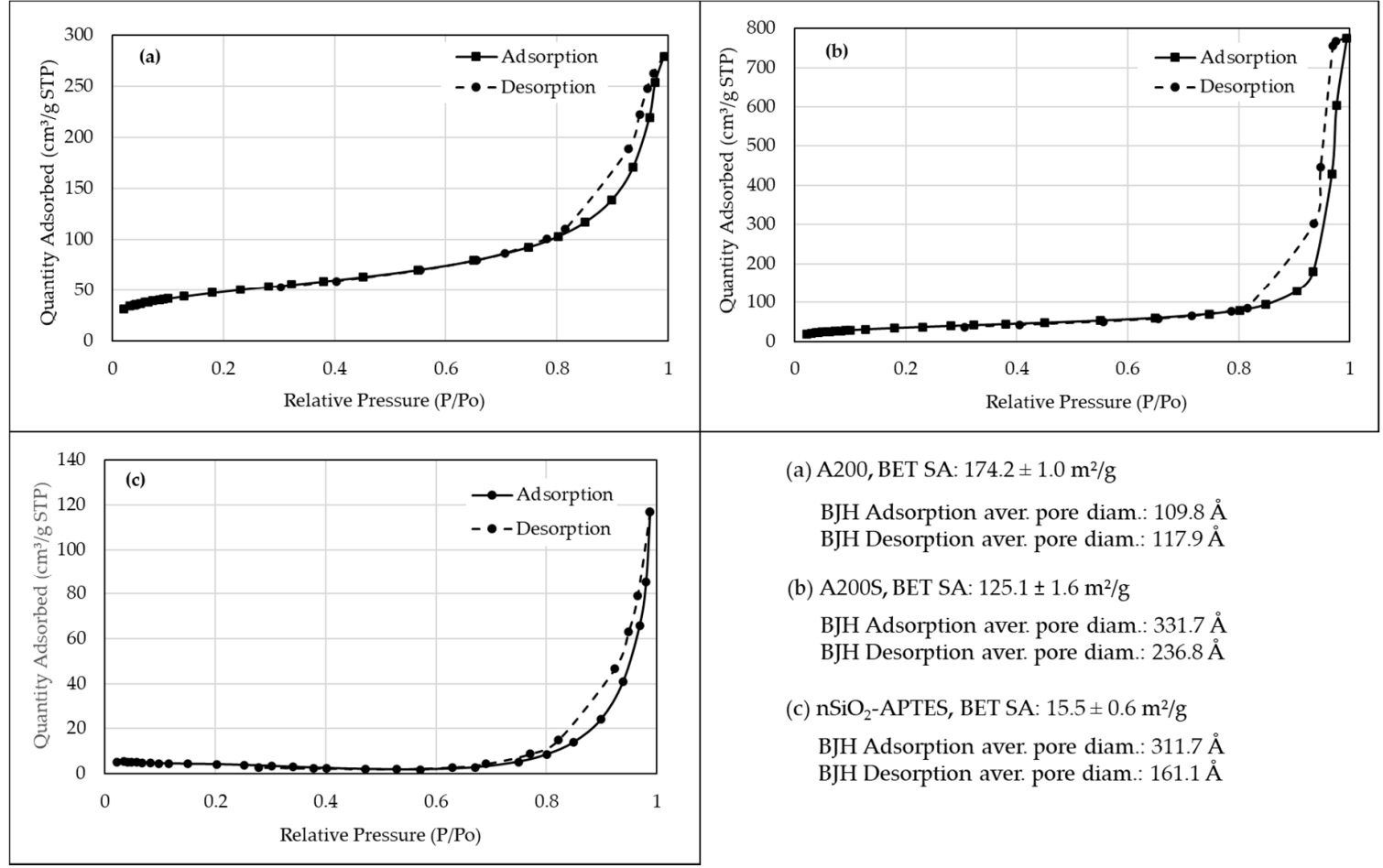

(a) A200, BET SA: $174.2 \pm 1.0 \mathrm{~m}^{2} / \mathrm{g}$

BJH Adsorption aver pore diam.: $109.8 \AA$ BJH Desorption aver. pore diam.: $117.9 \AA$

(b) A200S, BET SA: $125.1 \pm 1.6 \mathrm{~m}^{2} / \mathrm{g}$

BJH Adsorption aver pore diam.: $331.7 \AA$ BJH Desorption aver. pore diam.: $236.8 \AA$

(c) $\mathrm{nSiO}_{2}$-APTES, BET SA: $15.5 \pm 0.6 \mathrm{~m}^{2} / \mathrm{g}$ BJH Adsorption aver. pore diam.: $311.7 \AA$ BJH Desorption aver pore diam.: $161.1 \AA$

Figure 13. Sorption isotherms of $\mathrm{N}_{2}$ on (a) A200, (b) A200S and (c) $\mathrm{nSiO}_{2}-\mathrm{APTES}$ NPs at $77 \mathrm{~K}$.

The specific surface area of A200S NPs $\left(125.13 \pm 1.64 \mathrm{~m}^{2} / \mathrm{g}\right)$ is lower than that of the A200 NPs $\left(174.18 \pm 1.03 \mathrm{~m}^{2} / \mathrm{g}\right)$ due to the amino-functionalization of the NPs (Figure 13a,b). The surface area calculated for A200 NPs agrees with that reported by the manufacturer (Evonik) [81]. Additionally, the surface area of the A200S NPs $\left(125.13 \pm 1.64 \mathrm{~m}^{2} / \mathrm{g}\right)$ is higher than that of the $\mathrm{nSiO}_{2}$-APTES NPs 
$\left(15.52 \pm 0.63 \mathrm{~m}^{2} / \mathrm{g}\right)$ (Figure 13c) because the APTES can easily fill the uniform micropores and restrict the access of nitrogen into them [82].

\subsection{TGA Results}

The unmodified A200 show a slight weight loss of $1.4 \%$ between $100-800{ }^{\circ} \mathrm{C}$ (Figure 14), which was attributed to the surface dehydration and dehydroxylation [37]. By comparison, the first weight loss of the A200S NPs (24.3\%) occurred below $100{ }^{\circ} \mathrm{C}$, and it was assigned to the surface dehydration. The weight loss at temperatures above $100{ }^{\circ} \mathrm{C}$ is divided into two regions. The first weight-loss region occurs in the $100-350{ }^{\circ} \mathrm{C}$ range, and it can be attributed to the condensation of silanol groups of aminopropyl groups, and between them and the residual surface silanols on the NPs surface. The weight loss between 350 and $600{ }^{\circ} \mathrm{C}$ can be attributed to the thermal decomposition of the aminopropyl groups $[32,83]$. This result shows that the temperature for the decomposition of the aminopropyl groups on the NPs surface is much higher than the boiling point of the APTES $\left(217^{\circ} \mathrm{C}\right)$. The latter indicates that the aminopropyl groups are covalently attached to the $\mathrm{SiO}_{2} \mathrm{NPs}$ and have higher thermal stability than the modifier. No weight loss was observed above $600{ }^{\circ} \mathrm{C}$.

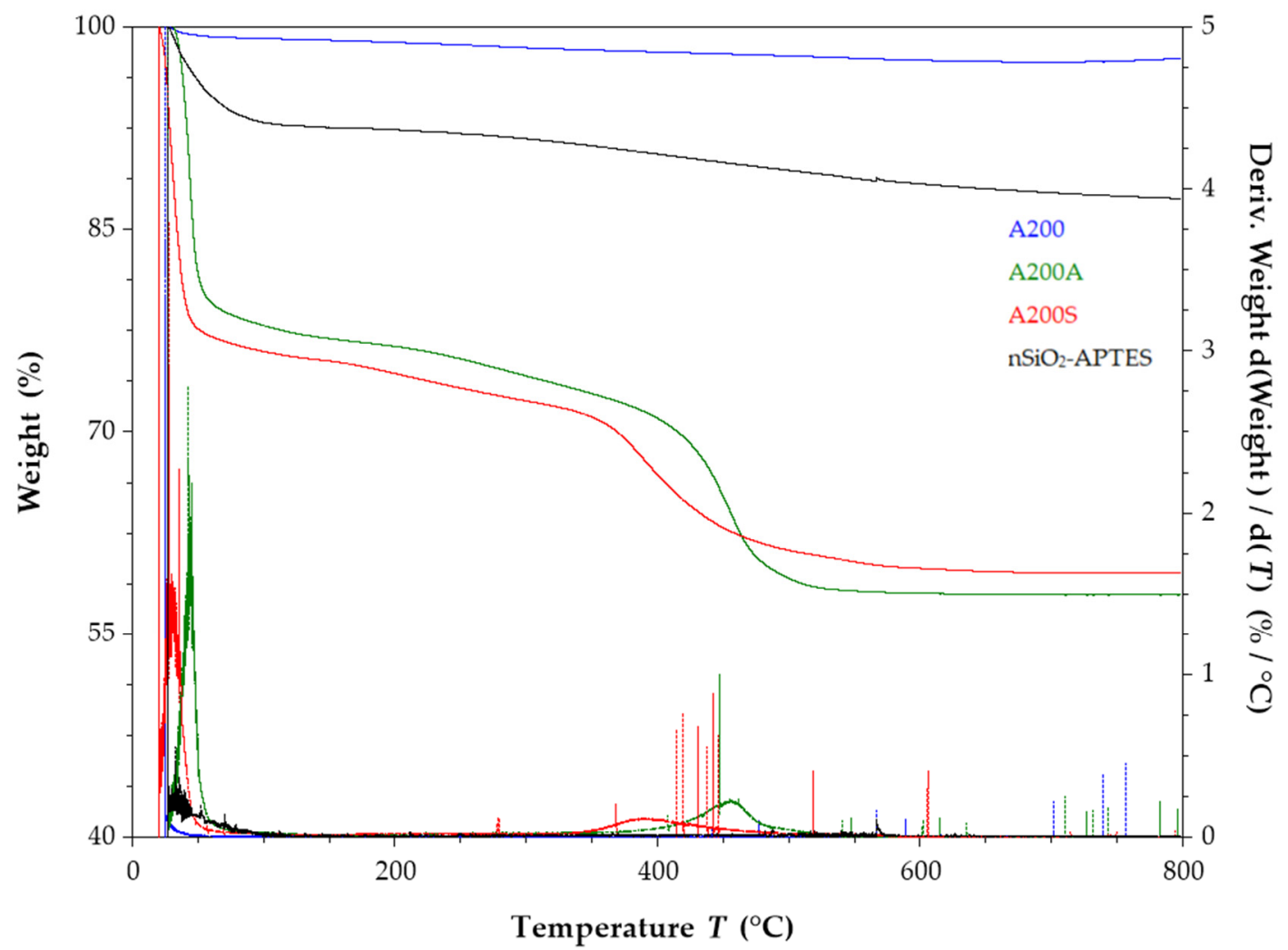

Figure 14. Thermograms of $\mathrm{A} 200, \mathrm{~A} 200 \mathrm{~A}, \mathrm{~A} 200 \mathrm{~S}$ and $\mathrm{nSiO}_{2}$-APTES NPs (heating rate of $10^{\circ} \mathrm{C} / \mathrm{min}$ in a nitrogen atmosphere).

On the other hand, the weight loss of $\mathrm{nSiO}_{2}$-APTES and A200S NPs was $2.8 \%$ and $11.2 \%$ in the range of 350 and $600{ }^{\circ} \mathrm{C}$, respectively. The latter indicates that the precipitated NPs have a smaller extent of functionalization with APTES than the fumed NPs. This behavior was attributed to the structural difference between them.

\section{Summary and Conclusions}

In this study, the activation and amino-functionalization of commercial fumed and precipitated silica NPs prepared by the Stöber method were evaluated. The NPs were characterized through 
XRD, FTIR, TGA, BET, SEM, and DLS. Additionally, the colloidal stability of the NPs in distilled water was predicted by $\zeta$-potential. The increase of the content of - $\mathrm{OH}$ groups on the A200 NPs surface by pretreatment with $\mathrm{NaOH}(1.90 \mathrm{mM} / \mathrm{g})$ was confirmed by potentiometric titration. The amino-functionalization of the NPs was confirmed by FTIR analysis. The comparative study of SEM, XRD nitrogen adsorption, and DLS results of A200S and $\mathrm{nSiO}_{2}-\mathrm{APTES}$ NPs showed that the precipitated NPs have a spherical shape, lower surface area, and larger particle size than the fumed ones. Upon the amino-functionalization of the NPs, the sign of the $\zeta$-potential values changed (from negative to positive). Still, the stability of the dispersions did not improve due to the hydrophobic interactions between NPs.

Author Contributions: Conceptualization, E.M. and A.R.R.B.; Data curation, M.C.R.-C.; Funding acquisition, E.M.; Methodology, M.C.R.-C.; Project administration, A.R.R.B.; Supervision, H.I.Q. and A.R.R.B.; Writing-original draft, M.C.R.-C., L.M.C. and A.R.R.B.; Writing-review \& editing, H.I.Q., L.M.C., E.M. and A.R.R.B. All authors have read and agreed to the published version of the manuscript.

Funding: This research was funded by Ecopetrol S.A. and the Universidad Industrial de Santander with a Master Cooperation Agreement No. 5222395; Act. 25.

Acknowledgments: The authors would like to acknowledge Ecopetrol S.A. and the Universidad Industrial de Santander for the logistical and financial support (Master Cooperation Agreement No. 5222395 Act. 25). Special thanks to the Polymer Research Group (GIP), the Catalysis Research Center (CICAT), the Microscopy laboratory of the Guatiguará Technology Park, and the Structural Chemistry Research Group (GIQUE) for their technical assistance. A portion of this work was presented at the 32nd International Conference on Nanoscience, Nanotechnology, and Nanoengineering" held in Rome, Italy, on 18-19 November, 2019.

Conflicts of Interest: The authors declare no conflict of interest.

\section{References}

1. Bindhu, M.; Umadevi, M. Silver and Gold Nanoparticles for Sensor and Antibacterial Applications. Spectrochim. Acta Part A Mol. Biomol. Spectrosc. 2014, 128, 37-45. [CrossRef]

2. Alsaba, M.T.; Al Dushaishi, M.F.; Abbas, A.K. A Comprehensive Review of Nanoparticles Applications in the Oil and Gas Industry. J. Pet. Explor. Prod. Technol. 2020, 10, 1389-1399. [CrossRef]

3. Sun, X.; Zhang, Y.; Chen, G.; Gai, Z. Application of Nanoparticles in Enhanced Oil Recovery: A Critical Review of Recent Progress. Energies 2017, 10, 345. [CrossRef]

4. Bera, A.; Belhaj, H. Application of Nanotechnology by Means of Nanoparticles and Nanodispersions in Oil Recovery-A Comprehensive Review. J. Nat. Gas Sci. Eng. 2016, 34, 1284-1309. [CrossRef]

5. Ponmani, S.; William, J.K.M.; Samuel, R.; Nagarajan, R.; Sangwai, J.S. Formation and Characterization of Thermal and Electrical Properties of $\mathrm{CuO}$ and $\mathrm{ZnO}$ Nanofluids in Xanthan Gum. Colloids Surf. A Physicochem. Eng. Asp. 2014. [CrossRef]

6. Stark, W.J.; Stoessel, P.R.; Wohlleben, W.; Hafner, A. Industrial Applications of Nanoparticles. Chem. Soc. Rev. 2015, 44, 5793-5805. [CrossRef] [PubMed]

7. Haddada, M.; Blanchard, J.; Casale, S.; Krafft, J.; Vallee, A.; Methivier, C.; Boujday, S. Optimizing the Immobilization of Gold Nanoparticles on Functionalized Silicon Surfaces: Amine- vs Thiol- Terminated Silane. Gold Bull. 2013, 46, 335-341. [CrossRef]

8. Milczarek, G.; Motylenko, M.; Sikorska, A.; Klapiszewski, Ł.; Wysokowski, M.; Bazhenov, V.; Piasecki, A.; Konował, E.; Ehrlich, H.; Jesionowski, T. Deposition of Silver Nanoparticles on Organically-Modified Silica in the Presence of Lignosulfonate. RSC Adv. 2014, 4, 52476-52484. [CrossRef]

9. Vázquez-Velázquez, A.R.; Velasco-Soto, M.A.; Pérez-García, S.A.; Licea-Jiménez, L. Functionalization Effect on Polymer Nanocomposite Coatings Based on $\mathrm{TiO}_{2}-\mathrm{SiO}_{2}$ Nanoparticles with Superhydrophilic Properties. Nanomaterials 2018, 8, 369. [CrossRef]

10. Colloidal, F; Particles, S. Adsorption of Cu ( II ) and Ni ( II ) Ions on Functionalized Colloidal Silica Particles Model Studies for Wastewater Treatment. Ph.D. Thesis, Université de Franche-Comté, Besançon, France, 2014.

11. Zienkiewicz-Strzałka, M.; Deryło-Marczewska, A.; Kozakevych, R.B. Silica Nanocomposites Based on Silver Nanoparticles-Functionalization and PH Effect. Appl. Nanosci. 2018, 8, 1649-1668. [CrossRef] 
12. Mallakpour, S.; Madani, M. A Review of Current Coupling Agents for Modification of Metal Oxide Nanoparticles. Prog. Org. Coatings 2015, 86, 194-207. [CrossRef]

13. Herrera, A.P.; Ojeda, K.A.; Penaloza, A.D.; Rincón, A. Evaluation of Colloidal Stability, Kinematic Viscosity and Flash Point of B10 Diesel/Biodiesel Blends Using Nano-Structured Additives Based on $\mathrm{Al}_{2} \mathrm{O}_{3}$ and Oleic Acid. J. Cienc. Technol. Future 2017, 6, 71-82. [CrossRef]

14. Dorigato, A.; D'Amato, M.; Pegoretti, A. Thermo-Mechanical Properties of High Density Polyethylene-Fumed Silica Nanocomposites: Effect of Filler Surface Area and Treatment. J. Polym. Res. 2012, 19, 1-11. [CrossRef]

15. Rodríguez-Quirós, H.A.; Casanova-Yepes, H.F. Effect of the Functionalization of Silica Nanoparticles as a Reinforcing Agent on Dental Composite Materials. Rev. Fac. Ing. 2015, 1, 36-44. [CrossRef]

16. Liberman, A.; Mendez, N.; Trogler, W.C.; Kummel, A.C. Synthesis and Surface Functionalization of Silica Nanoparticles for Nanomedicine. Surf. Sci. Rep. 2014, 69, 132-158. [CrossRef]

17. Roy, S.; Dixit, C.K.; Woolley, R.; MacCraith, B.D.; Okennedy, R.; McDonagh, C. Novel Multiparametric Approach to Elucidate the Surface Amine-Silanization Reaction Profile on Fluorescent Silica Nanoparticles. Langmuir 2010, 26, 18125-18134. [CrossRef]

18. Zhang, J.F.; Chen, Y.; Facile, B.M. Functionalization of PDMS Elastomer Surfaces Using Thiolene Click Chemistry. Langmuir 2013, 29, 12432-12442. [CrossRef]

19. Zhu, D.; Han, Y.; Zhang, J.; Li, X.; Feng, Y. Enhancing Rheological Properties of Hydrophobically Associative Polyacrylamide Aqueous Solutions by Hybriding with Silica Nanoparticles. J. Appl. Polym. Sci. 2014, 40876, 1-8. [CrossRef]

20. Corredor, L.M.; Hemmati-Sarapardeh, A.; Husein, M.M.; Dong, M.; Maini, B.B. Rheological Behavior of Surface Modified Silica Nanoparticles Dispersed in Partially Hydrolyzed Polyacrylamide and Xanthan Gum Solutions: Experimental Measurements, Mechanistic Understanding, and Model Development. Energy Fuels 2018, 32, 10628-10638. [CrossRef]

21. Mahdavian, A.R.; Ashjari, M.; Makoo, A.B. Preparation of Poly (Styrene-Methyl Methacrylate) $/ \mathrm{SiO}_{2}$ Composite Nanoparticles via Emulsion Polymerization. An Investigation into the Compatiblization. Eur. Polym. J. 2007, 43, 336-344. [CrossRef]

22. Wei, L.; Hu, N.; Zhang, Y. Synthesis of Polymer-Mesoporous Silica Nanocomposites. Materials (Basel) 2010, 3 , 4066-4079. [CrossRef] [PubMed]

23. Xue, Z.; Foster, E.; Wang, Y.; Nayak, S.; Cheng, V.; Ngo, V.W.; Pennell, K.D.; Bielawski, C.W.; Johnston, K.P. Effect of Grafted Copolymer Composition on Iron Oxide Nanoparticle Stability and Transport in Porous Media at High Salinity. Energy Fuels 2014, 28, 3655-3665. [CrossRef]

24. Foster, E.L.; Xue, Z.; Roach, C.M.; Larsen, E.S.; Bielawski, C.W.; Johnston, K.P. Iron Oxide Nanoparticles Grafted with Sulfonated and Zwitterionic Polymers: High Stability and Low Adsorption in Extreme Aqueous Environments. ACS Macro Lett. 2014, 3, 867-871. [CrossRef]

25. Ponnapati, R.; Karazincir, O.; Dao, E.; Ng, R.; Mohanty, K.K.; Krishnamoorti, R. Polymer-Functionalized Nanoparticles for Improving Waterflood Sweep Efficiency: Characterization and Transport Properties. IEC Res. Ind. Eng. Chem. Res. 2011, 50, 13030-13036. [CrossRef]

26. Corredor, L.M.; Husein, M.; Maini, B. Impact of PAM-Grafted Nanoparticles on the Performance of Hydrolyzed Polyacrylamide Solutions for Heavy Oil Recovery at Different Salinities. Submitt. Ind. Eng. Chem. Res. 2019, 58, 9888-9899. [CrossRef]

27. Tapia, J.F.D.; Lee, J.Y.; Ooi, R.E.H.; Foo, D.C.Y.; Tan, R.R. Optimal $\mathrm{CO}_{2}$ Allocation and Scheduling in Enhanced Oil Recovery (EOR) Operations. Appl. Energy 2016, 184, 337-345. [CrossRef]

28. Corredor, L.M.; Aliabadian, E.; Husein, M.; Chen, Z.; Maini, B.; Sundararaj, U. Heavy Oil Recovery by Surface Modified Silica Nanoparticle/HPAM Nanofluids. Fuel 2019, 252, 622-634. [CrossRef]

29. Prado, L.; Sriyai, M.; Ghislandi, M.; Barros, A.; Schulte, K. Surface Modification of $\mathrm{TiO}_{2}$ nanoparticles with Silane Coupling Agents. J. Braz. Chem. Soc. 2010, 21, 2238-2245. [CrossRef]

30. Corredor, L.M.; Husein, M.M.; Maini, B.B. A Review of Polymer Nanohybrids for Oil Recovery. Adv. Colloid Interface Sci. 2019, 272, 102018. [CrossRef]

31. Pham, K.N.; Fullston, D.; Surface, K.S.-C. Charge Modification of Nano-Sized Silica Colloid. Aust. J. Chem. 2007, 60, 662-666. [CrossRef] 
32. Rahman, I.A.; Jafarzadeh, M.; Sipaut, C.S. Synthesis of Organo-Functionalized Nanosilica via a Co-Condensation Modification Using $\gamma$-Aminopropyltriethoxysilane (APTES). Ceram. Int. 2009, 35, 1883-1888. [CrossRef]

33. Uyanik, M. Synthesis and Characterization of $\mathrm{TiO}_{2}$ Nanostars. Ph.D. Thesis, Universität des Saarlandes, Saarbrücken, Germany, 2008.

34. Nazir, T.; Afzal, A.; Siddiqi, H.M.; Ahmad, Z.; Dumon, M. Thermally and Mechanically Superior Hybrid Epoxy-Silica Polymer Films via Sol-Gel Method. Prog. Org. Coat. 2010, 69, 100-106. [CrossRef]

35. Fattahi, N.; Ramazani, A.; Kinzhybalo, V. Imidazole-Functionalized $\mathrm{Fe}_{3} \mathrm{O}_{4}$ /Chloro-Silane Core-Shell Nanoparticles: An Efficient Heterogeneous Organocatalyst for Esterification Reaction. Silicon 2019, 11, 1745-1754. [CrossRef]

36. Hubner, E.; Allgaier, J.; Meyer, M.; Pyckhout-hintzen, W.; Richter, D. Synthesis of Polymer/Silica Hybrid Nanoparticles Using Anionic Polymerization Techniques. Macromolecules 2010, 43, 856-867. [CrossRef]

37. Shen, S.; Kiong Ng, W.; Chia, L.; Dong, Y.; Tan, R. Sonochemical Synthesis of (3-Aminopropyl) Triethoxysilane-Modified Monodispersed Silica Nanoparticles for Protein Immobilization. Mater. Res. Bull. 2011, 46, 1665-1669. [CrossRef]

38. Yoon, D.H.; Jang, J.W.; Cheong, I.W. Synthesis of Cationic Polyacrylamide/Silica Nanocomposites from Inverse Emulsion Polymerization and Their Flocculation Property for Papermaking. Colloids Surf. A Physicochem. Eng. Asp. 2012, 411, 18-23. [CrossRef]

39. Qu, R.; Ma, X.; Wang, M.; Sun, C.; Sun, X.; Sun, S.; Zhang, Y.; Yin, P. Homogeneous Preparation of Polyamidoamine Grafted Silica Gels and Their Adsorption Properties as $\mathrm{Au}^{3+}$ Adsorbents. J. Ind. Eng. Chem. 2014, 20, 4382-4392. [CrossRef]

40. Jiang, R.; Kunz, H.R.; Fenton, J.M. Composite Silica/Nafion ${ }^{\circledR}$ Membranes Prepared by Tetraethylorthosilicate Sol-Gel Reaction and Solution Casting for Direct Methanol Fuel Cells. J. Memb. Sci. 2006, 272, 116-124. [CrossRef]

41. Tripathi, V.S.; Kandimalla, V.B.; Ju, H. Preparation of Ormosil and Its Applications in the Immobilizing Biomolecules. Sens. Actuators B Chem. 2006, 114, 1071-1082. [CrossRef]

42. Ulu, A.; Noma, S.A.A.; Koytepe, S.; Ates, B. Magnetic $\mathrm{Fe}_{3} \mathrm{O}_{4} @ \mathrm{MCM}-41$ Core-Shell Nanoparticles Functionalized with Thiol Silane for Efficient l-Asparaginase Immobilization. Artif. Cells Nanomed. Biotechnol. 2018, 46, 1035-1045. [CrossRef]

43. Lee, D.W.; Yoo, B.R. Advanced Silica/Polymer Composites: Materials and Applications. J. Ind. Eng. Chem. 2016, 1-12. [CrossRef]

44. Cao, J.; Song, T.; Zhu, Y.; Wang, S.; Wang, X.; Lv, F.; Jiang, L.; Sun, M. Application of Amino-Functionalized Nanosilica in Improving the Thermal Stability of Acrylamide-Based Polymer for Enhanced Oil Recovery. Energy Fuels 2018, 32, 246-254. [CrossRef]

45. Cao, J.; Song, T.; Wang, X.; Zhu, Y.; Wang, S.; Zhao, M.; Miao, Y.; Zhang, J. Studies on the Rheological Properties of Amphiphilic Nanosilica and a Partially Hydrolyzed Polyacrylamide Hybrid for Enhanced Oil Recovery. Chem. Eng. Sci. 2019, 206, 146-155. [CrossRef]

46. Jafarzadeh, M.; Ab Rahman, I.; Sipaut, C.S. Synthesis of Silica-Polypyrrole Core-Shell Nanocomposite Using in Situ $\gamma$-Aminopropyltriethoxysilane (APTES)-Modified Nanosilica. Synth. Met. 2012, 162, 466-476. [CrossRef]

47. Yoncheva, K.; Popova, M.; Szegedi, A.; Mihaly, J.; Tzankov, B.; Lambov, N. Functionalized Mesoporous Silica Nanoparticles for Oral Delivery of Budesonide. J. Solid State Chem. 2014, 211, 154-161. [CrossRef]

48. Cheang, T.Y.; Tang, B.; Xu, A.W.; Chang, G.Q.; Hu, Z.J.; He, W.L.; Xing, Z.H.; Xu, J.B.; Wang, M.; Wang, S.M. Promising Plasmid DNA Vector Based on APTESmodified Silica Nanoparticles. Int. J. Nanomed. 2012, 7, 1061-1067. [CrossRef]

49. Yang, H.; Zheng, K.; Zhang, Z.; Shi, W.; Jing, S.; Wang, L.; Zheng, W.; Zhao, D.; Xu, J.; Zhang, P. Adsorption and Protection of Plasmid DNA on Mesoporous Silica Nanoparticles Modified with Various Amounts of Organosilane. J. Colloid Interface Sci. 2012, 369, 317-322. [CrossRef]

50. Wang, Y.; Sun, Y.; Wang, J.; Yang, Y.; Li, Y.; Yuan, Y.; Liu, C. Charge-Reversal APTES-Modified Mesoporous Silica Nanoparticles with High Drug Loading and Release Controllability. ACS Appl. Mater. Interfaces 2016, 8, 17166-17175. [CrossRef] 
51. Karim, A.H.; Jalil, A.A.; Triwahyono, S.; Sidik, S.M.; Kamarudin, N.H.N.; Jusoh, R.; Jusoh, N.W.C.; Hameed, B.H. Amino Modified Mesostructured Silica Nanoparticles for Efficient Adsorption of Methylene Blue. J. Colloid Interface Sci. 2012, 386, 307-314. [CrossRef]

52. Gu, H.; Guo, Y.; Wong, S.Y.; He, C.; Li, X.; Shim, V.P.W. Effect of Interphase and Strain-Rate on the Tensile Properties of Polyamide 6 Reinforced with Functionalized Silica Nanoparticles. Compos. Sci. Technol. 2013, 75, 62-69. [CrossRef]

53. Ruiz-Cañas, M.C.; Quintero, H.I.; Corredor, L.M.; Manrique, E.; Romero Bohórquez, A.R. New Nanohybrid Based on Hydrolyzed Polyacrylamide and Silica Nanoparticles: Morphological, Structural and Thermal Properties. Polymers (Basel) 2020, 12, 1152. [CrossRef] [PubMed]

54. Stober, W.; Fink, A. Controlled Growth of Monodispersed Silica Spheres in the Micron Size Range. J. Colloid Interface Sci. 1968, 26, 62-69. [CrossRef]

55. Rahman, I.A.; Padavettan, V. Synthesis of Silica Nanoparticles by Sol-Gel: Size-Dependent Properties, Surface Modification, and Applications in Silica-Polymer Nanocomposites-A Review. J. Nanomater. 2012, 1-15. [CrossRef]

56. Lin, O.H.; Akil, H.M.; Ishak, Z.A.M. Characterization and Properties of Activated Nanosilica/Polypropylene Composites with Coupling Agents. Polym. Compos. 2009, 30, 1693-1700. [CrossRef]

57. Chen, S.; Hayakawa, S.; Shirosaki, Y.; Fujii, E.; Kawabata, K.; Tsuru, K.; Osaka, A. Sol-Gel Synthesis and Microstructure Analysis of Amino-Modified Hybrid Silica Nanoparticles from Aminopropyltriethoxysilane and Tetraethoxysilane. J. Am. Ceram. Soc. 2009, 92, 2074-2082. [CrossRef]

58. Kang, S.; Hong, S.I.; Choe, C.R.; Park, M.; Rim, S.; Kim, J. Preparation and Characterization of Epoxy Composites Filled with Functionalized Nanosilica Particles Obtained via Sol-Gel Process. Polymer (Guildf) 2001, 42, 879-887. [CrossRef]

59. Rouquerol, F.; Rouquerol, J.; Sing, K. Adsorption by Powders and Porous Solids; Academic Press: Cambridge, MA, USA, 1999.

60. E2550-17. Standard Test Method for Thermal Stability by Thermogravimetry; ASTM International: West Conshohocken, PA, USA, 2017; Volume 11, pp. 1-5. [CrossRef]

61. Shang, H.; Lu, Y.; Zhao, F.; Chao, C.; Zhang, B.; Zhang, H. Preparing High Surface Area Porous Carbon from Biomass by Carbonization in Molten Salt Medium. RSC Adv. 2015, 5, 75728-75734. [CrossRef]

62. Kumar, R.D.; Kannan, G.K.; Kadirvelu, K.J. Populus Tree Wood: A Noble Bioresource from Western Himalayas for the Development of Various Carbon Types for the Effective Application in Environment Protection i.e., Phenol Adsorption from Wastewater. J. Bioremed. Biodegrad. 2017, 8, 1-11. [CrossRef]

63. Hamid, S.; Syed, W.H.; Mohammad, G.-M. Synthesis and Characterization of Amino-Functionalized Mesoporous Silicate MCM-41 for Removal of Toxic Metal Ions. Chin. J. Chem. 2009, 27, 915-919. [CrossRef]

64. Marler, B.; Oberhagemann, U.; Vortmann, S.; Gies, H. Influence of the Sorbate Type on the XRD Peak Intensities of Loaded MCM-41. Microporous Mater. 1996, 6, 375-383. [CrossRef]

65. Mercier, L.; Pinnavaia, T.J. Heavy Metal Ion Adsorbents Formed by the Grafting of a Thiol Functionality to Mesoporous Silica Molecular Sieves: Factors Affecting $\mathrm{Hg}(\mathrm{II})$ Uptake. Environ. Sci. Technol. 1998, 32, 2749-2754. [CrossRef]

66. Ay, F.; Aydinli, A. Comparative Investigation of Hydrogen Bonding in Silicon Based PECVD Grown Dielectrics for Optical Waveguides. Opt. Mater. 2004, 26, 33-46. [CrossRef]

67. Benmessaoud, A. Caracterización de Subóxidos de Silicio Obtenidos por las Técnicas de PECVD. Ph.D. Thesis, Universidad Autónoma de Barcelona, Barcelona, Spain, 2001.

68. Fukuda, Y.; Zhou, W.; Furuya, K.; Suzuki, H. Photoluminescence Change of As-Prepared and Aged Porous Silicon with $\mathrm{NaOH}$ Treatment. J. Electrochem. Soc. 1999, 146, 2697. [CrossRef]

69. Vázquez-Valerdi, D.E.; Luna-López, J.A.; García-Salgado, G.; Carrillo López, J.; Diaz-Becerril, T.; Rosendo, E.; Juárez-Santiesteban, H. Propiedades Ópticas, de Composición y Morfológicas de Películas Delgadas de SiOx Depositadas Por HFCVD. Superf. Vacío 2011, 24, 54-60.

70. Vansant, E.F.; Van Der Voort, P.; Vrancken, K.C. Characterization and Chemical Modification of the Silica Surface; Elsevier: Amsterdam, The Netherlands, 1995.

71. Al-Oweini, R.; El-Rassy, H. Synthesis and Characterization by FTIR Spectroscopy of Silica Aerogels Prepared Using Several Si(OR)4 and R"Si(OR')3 Precursors. J. Mol. Struct. 2009, 919, 140-145. [CrossRef]

72. Kim, J.; Seidler, P.; Wan, L.S.; Fill, C. Formation, Structure, and Reactivity of Amino-Terminated Organic Films on Silicon Substrates. J. Colloid Interface Sci. 2009, 329, 114-119. [CrossRef] 
73. Vandenberg, E.T.; Bertilsson, L.; Liedberg, B.; Uvdal, K.; Erlandsson, R.; Elwing, H.; Lundström, I. Structure of 3-Aminopropyl Triethoxy Silane on Silicon Oxide. J. Colloid Interface Sci. 1991, 147, 103-118. [CrossRef]

74. Clogston, J.; Patri, A. Characterization of Nanoparticles Intended for Drug Delivery; McNeil, S.E., Ed.; Humana Press: New York, NY, USA, 2011; Volume 697, pp. 63-70. [CrossRef]

75. Sikora, A.; Bartczak, D.; Geißler, D.; Kestens, V.; Roebben, G.; Ramaye, Y.; Varga, Z.; Palmai, M.; Shard, A.G.; Goenaga-Infante, H.; et al. A Systematic Comparison of Different Techniques to Determine the Zeta Potential of Silica Nanoparticles in Biological Medium. Anal. Methods 2015, 7, 9835-9843. [CrossRef]

76. Llinàs, M.C.; Sánchez-García, D. Nanopartículas de Sílice: Preparación y Aplicaciones En Biomedicina. Afinidad LXXI 2014, 565, 20-31.

77. Alothman, Z.A. A Review: Fundamental Aspects of Silicate Mesoporous Materials. Materials (Basel) 2012, 5, 2874-2902. [CrossRef]

78. Vallejo, S.S. Estudio de Propiedades y Aplicaciones de Nanoestructuras de Sílice Mesoporosa y Aluminosilicatos En El Calzado. Ph.D. Thesis, Universidad de la Rioja, La Rioja, Spain, 2017.

79. Thommes, M.; Kaneko, K.; Neimark, A.V.; Olivier, J.P.; Rodriguez-Reinoso, F.; Rouquerol, J.; Sing, K.S.W. Physisorption of Gases, with Special Reference to the Evaluation of Surface Area and Pore Size Distribution (IUPAC Technical Report). Pure Appl. Chem. 2015, 87, 1051-1069. [CrossRef]

80. Goeppert, A.; Meth, S.; Prakash, G.K.S.; Olah, G.A. Nanostructured Silica as a Support for Regenerable High-Capacity Organoamine-Based $\mathrm{CO}_{2}$ Sorbents. Energy Environ. Sci. 2010, 3, 1949-1960. [CrossRef]

81. Evonik. Aerosil_Fumed Silica: Technical Overview; Evonik: Essen, Germany, 2015.

82. Xia, K.; Ferguson, R.Z.; Losier, M.; Tchoukanova, N.; Brüning, R. Synthesis of Hybrid Silica Materials with Tunable Pore Structures and Morphology and Their Application for Heavy Metal Removal from Drinking Water Synthesis of Hybrid Silica Materials with Tunable Pore Structures and Morphology and Their Application for H. J. Hazard. Mater. 2010, 183, 554-564. [CrossRef] [PubMed]

83. Jaroniec, C.P.; Gilpin, R.K.; Jaroniec, M. Adsorption and Thermogravimetric Studies of Silica-Based Amide Bonded Phases. J. Phys. Chem. B 1997, 101, 6861-6866. [CrossRef]

Sample Availability: Samples of the compounds A200S and nSiO2-APTES are available from the authors.

(C) 2020 by the authors. Licensee MDPI, Basel, Switzerland. This article is an open access article distributed under the terms and conditions of the Creative Commons Attribution (CC BY) license (http://creativecommons.org/licenses/by/4.0/). 